Article

SILVA, D.R.O. ${ }^{1 *}$

VARGAS, L. ${ }^{2}$

AGOSTINETTO, D. ${ }^{3}$

SANTOS, F.M. ${ }^{4}$

\section{Photosynthetic Performance of Glyphosate Resistant aNd GlyPhosate SUSCEPTIBLE HaIRY FLEABANE UNDER LIGHT INTENSITY}

\author{
Desempenho Fotossintético de Buva Resistente e Suscetível ao Glyphosate sob \\ Intensidade Luminosa
}

\begin{abstract}
Herbicide resistance can confer lower competitive abilities; however scarse information is available about the photosynthetic performance between glyphosate-resistant and -susceptible hairy fleabane biotypes coming from areas with similar weed management history. Thus, the goal was to evaluate the photosynthetic performance under different light intensities between glyphosateresistant and -susceptible hairy fleabane biotypes, from RR soybean fields with a similar weed management history. The tested factors were glyphosate resistant and susceptible biotypes and 12 levels of photosynthetic photon flux density. Plants were cultivated in plastic cups, and at the stage of 10-12 leaves they were subjected to treatments with artificial lighting systems. The net photosynthetic rate, stomatal conductance, substomatal $\mathrm{CO}_{2}$ concentration, transpiration rate, instantaneous water use efficiency, light compensation point and quantum yield were evaluated. In all the evaluated photosynthetic parameters, biotype R showed superior characteristics compared to susceptible biotypes, with the exception of the transpiration rate, where there were no differences. The differences between biotypes may not be associated to glyphosate resistance or susceptibility, but to the evolutionary characteristics of the biotypes.
\end{abstract}
Keywords: Conyza bonariensis, ecological adaptability, photosynthetic photon flux; carbon assimilation rate, gas exchange, light response curve.

\begin{abstract}
RESUMO - A resistência a herbicidas pode conferir menor capacidade competitiva, porém limitadas informações estão disponíveis sobre o desempenho fotossintético entre biótipos resistentes e suscetíveis ao glyphosate provenientes de área com similar histórico no manejo de plantas daninhas. Assim, o objetivo deste trabalho foi avaliar o desempenho fotossintético sob diferentes intensidades luminosas entre biótipos de buva resistente e suscetível ao glyphosate, oriundos de área de lavoura de soja Roundup Ready ${ }^{\circledR}$ com histórico similar de manejo de plantas daninhas. Os fatores testados foram biótipos resistentes e suscetíveis ao glyphosate e 12 níveis de densidade de fluxo de fótons fotossintéticos. As plantas foram cultivadas em copos plásticos e, no estádio de 10-12 folhas submetidas ao tratamento com sistema de luz artificial. Foram avaliados taxa fotossintética líquida, condutância estomática, concentração de $\mathrm{CO}_{2}$ subestomática, taxa transpiratória, eficiência instantânea do uso da água, ponto de compensação de luz e rendimento quântico. Em todos os parâmetros fotossintéticos avaliados, o biótipo $R$ apresentou características superiores comparado ao biótipo suscetível, com exceção da taxa
\end{abstract}

* Corresponding author:

<diecsonros@hotmail.com>

Received: August 18, 2016

Approved: October 3, 2016

Planta Daninha 2017; v35:e017166275

1 Universidade Federal de Santa Maria, Frederico Westphalen-RS, Brasil; ${ }^{2}$ Embrapa Trigo, Passo Fundo-RS, Brasil,

${ }^{3}$ Universidade Federal de Pelotas, Capão do Leão-RS, Brasil. ${ }^{4}$ Instituto Federal do Rio Grande do Sul, Núcleo de Ciências Agrícolas, Sertão, Rio Grande do Sul, Brasil. 
transpiratória, em que não houve diferenças. As diferenças entre biótipos podem não estar associadas à resistência ou suscetibilidade ao glyphosate, e sim às características evolutivas dos biótipos.

Palavras-chave: Conyza bonariensis, adaptabilidade ecológica, fluxo de fótons fotossintéticos, taxa de assimilação de carbono, troca de gases, curva-resposta de luz.

\section{INTRODUCTION}

Glyphosate is one of the most used herbicides in the world and it presents resistance in various weed species. Currently, there are 35 cases of weed resistance to glyphosate in the world (Heap, 2016). In Brazil, there are eight species presenting resistance to this herbicide; the first report dates back to 2003 for Lolium mutiflorum in the state of Rio Grande do Sul (Roman et al., 2004). Moreover, other species have presented resistance to glyphosate, among which Conyza bonariensis, C. canadensis, C. sumatrensis, Digitaria insularis, Chloris elata, Eleusine indica and Amarhanthus palmeri (Heap, 2016).

In Brazil, the first case of glyphosate resistance on Conyza bonariensis was documented in Roundup Ready (RR) soybean crops in Rio Grande do Sul (Vargas et al., 2007). Since then, this species have become a problem for soybean farmers, due to the high dispersion capacity of the seeds and the ability to infest adjacent areas (Dauer et al., 2009).

Developing strategies to manage herbicide-resistant weeds requires understanding the population dynamic of plants and the potential impact of biotypes on the environment (Shrestha et al., 2010). Weed resistance to herbicides may give low capacity to some metabolism level, defense system, development and reproduction of plants (Vila-Aiub et al., 2009). However, studies have been contradictory to the response of the adaptive characteristics between glyphosateresistant and -susceptible biotypes.

Under non-competitive conditions, glyphosate-susceptible biotypes of $C$. bonariensis and C. canadensis presented higher absolute growth than the resistant biotypes, which means that glyphosate-resistant plants had a negative performance in terms of development capacity (Moreira et al., 2010). On the other hand, for glyphosate-resistant C. canadensis, there was a quicker initial development than the susceptible biotype, and under conditions of water deficit, it was more competitive (Shrestha et al., 2010). In another study, Kaspary et al. (2014) observed that the resistant hairy fleabane biotype contained higher contents of photo-synthetic pigments than the susceptible biotype. In these cases, the change caused in metabolism is beneficial in a competitive environment, and plants with a quicker initial growth may have higher capacity to capture the resources for their survival and reproduction.

Adaptability characteristics that describe the difference between resistant and susceptible biotypes are usually based on the success of survival, competitiveness and reproduction. The most common adaptation characteristics include: germination rate, plant vigor, growth rate, phenological development and seed production. However, changes in these characteristics are conditioned by alterations in the plant metabolism, which includes alterations in the photosynthetic metabolism.

The evaluation of photosynthetic parameters in herbicide-resistant plants may be an important method to distinguish the ecologic ability among biotypes. The method is reliable, immediate, easily measurable and not destructive, enabling to verify the changes induced in the photosynthetic metabolism.

The results found in literature about effects on the adaptability of plants according to glyphosate resistance suggest the glyphosate-resistant biotypes may present some benefits in the photosynthetic performance under different luminosities (Shrestha et al., 2010, 2014; Kaspary et al., 2014, 2015). However, until now, no information has been related to changes in this photosynthetic performance among hairy fleabane biotypes coming from areas with similar history in the management of weeds. Thus, the goal of this study was to evaluate the photosynthetic performance, under different light intensities, between glyphosate-resistant and -susceptible hairy fleabane biotypes, coming from $\mathrm{RR}^{\circledR}$ soybean cultivation areas with similar history in managing weeds. 


\section{MATERIAL AND METHODS}

Preliminary collection studies and glyphosate resistance tests were performed. In the 2008/ 2009 harvest, Conyza bonariensis seeds were collected in 390 soybean cultivations in Rio Grande do Sul; a single plant was sampled per location - this plant was identified as surviving from the glyphosate management on RR soybean. In 2010, seeds from each biotype (F1 plants) were placed for germination in plastic pots $(8 \mathrm{~L})$ containing sieved soil classified as Red-Yellow Argisol. When seedlings reached the five-leaf stage, glyphosate was applied at doses of 360 and 2,160 g a.e. ha-1, using a $\mathrm{CO}_{2}$ pressurized backpack sprayer, equipped with fan-type nozzles and 115.02 tips and spray volume equal to $120 \mathrm{~L} \mathrm{ha}^{-1}$. Plants surviving to the highest dose were considered resistant, and the ones that were controlled by the lowest dose were considered susceptible.

One glyphosate-resistant (R) and one susceptible (S) biotype, coming from soybean production fields in the cities of Cruz Alta and Não-Me-Toque, respectively, were then chosen. These biotypes were chosen considering that in both places there is a similar history of weed management in the soybean culture, with glyphosate applications for at least four years, and also because they were geographically close $(80 \mathrm{~km})$ and with similar edaphoclimatic conditions. In 2011, in a greenhouse, F2 seeds from these two biotypes were placed for germination in plastic cups $(500 \mathrm{~mL})$, containing Garden Plus Turfa Fértil ${ }^{\circledR}$ substrate. After the emergence, thinning was performed, leaving three plants per experimental unit. Irrigation was periodically made on trays, containing the plastic cups on the base, where water was absorbed by capillarity.

The experimental design was completely randomized with ten replications. The tested factors were: hairy fleabane biotypes ( $R$ and $\mathrm{S}$ ) and 12 levels of photosynthetic photon flow density (PPFD) $\left(0,10,20,40,80,100,250,500,750,1,000,1,500\right.$ and $\left.2,000 \mu \mathrm{mol} \mathrm{m}^{-2} \mathrm{~s}^{-1}\right)$. On day 56 after emergence (at the 10-12 leaves stage), the liquid photosynthetic rate (A) and the transpiration rate $(\mathrm{E})$, the stomatal conductance (gs) and the substomatal $\mathrm{CO}_{2}$ concentration (Ci) were measured with the use of an infrared gas analyzer (IRGA - LI-6400XT model), equipped with an artificial light and automatic $\mathrm{CO}_{2}$ injection system. The equipment was set for $400 \mu \mathrm{mol} \mathrm{mol}^{-1} \mathrm{CO}_{2}$ concentration (in order to avoid fluctuations in the measures), leaf temperature of $20{ }^{\circ} \mathrm{C}$ and air flow of $500 \mu \mathrm{mol} \mathrm{s}{ }^{-1}$. PPFD levels were induced by a LED light source at the time of scanning. Evaluations were made in the morning, taking the last fully expanded leaf.

Subsequently, the instantaneous water use efficiency (WUE) was calculated by the relation between the liquid photosynthetic rate and the transpiration rate. Moreover, the light compensation point (LCP) was estimated by the level of light where the plant did not present liquid $\mathrm{CO}_{2}$ fixation, estimated by the interception values of the axis of the relation between photosynthetic rate and PPFD and the quantum yield (QY), calculated by the inclination of the linear regression between photosynthetic rate and incident light. At the end of the scanning, the leaf number of the biotypes and the dry matter of the aerial part, obtained by drying in an oven at $60{ }^{\circ} \mathrm{C}$ for 72 hours, were measured.

Data were submitted to analysis of variance $(p<0.05)$ and, when there were significant differences, factors were compared by Least Significant Difference (LSD) ( $<<0.05)$. The interaction between the factors was tested and, when significant, it was analyzed by non-linear hyperbole type equations, adjusted for A, gs, E and WUE, and exponential ones for Ci. For the analysis of the compensation point and quantum yield, the linear equation was adjusted for PPFD from 0 to $100 \mu \mathrm{mol} \mathrm{m} \mathrm{s}^{-2}$. The charts were created with the help of the Sigma Plot software, version 10.0.

\section{RESULTS AND DISCUSSION}

The interaction between biotype and PPFD as for liquid photosynthetic rate (A), stomatal conductance (gs), substomatal $\mathrm{CO}_{2}$ concentration (Ci) and instantaneous water use efficiency (WUE) was tested, but only the PPFD effect for the transpiration rate (E) (Figures 1 and 2). However, no growth difference was observed between the hairy fleabane biotypes as for leaf number and dry matter (data not presented). The growth similarity of the hairy fleabane biotypes may be related to the short period of the experiment ( 56 days after emergence), associated to the development of plants in the coldest months of the year and the lowest luminosity (May to July), which may result in a similar initial growth for both biotypes. In studies conducted for longer 
periods and/or under higher luminosity and temperature conditions, there have been differences in the development between the biotypes (Shrestha et al., 2010; Kaspary et al., 2015).

Biotypes $\mathrm{R}$ and $\mathrm{S}$ presented an increase in A with the increase of artificial light; however, the maximum A, estimated by the hyperbole model, differed between the biotypes, which presented values of 17.12 and $10.28 \mu \mathrm{mol} \mathrm{CO}_{2} \mathrm{~m}^{-2} \mathrm{~s}^{-1}$ for the biotypes $\mathrm{R}$ and $\mathrm{S}$, respectively (Figure $1 \mathrm{~A}$ ). Starting from a $250 \mu \mathrm{mol} \mathrm{m} \mathrm{m}^{-2} \mathrm{~s}^{-1} \mathrm{PPFD}$, the R biotype presented higher A values than the estimated ones for the $\mathrm{S}$ biotype. These results may implicate the differential capacity of the light use between the biotypes, which would result in the change of the competition potential, mainly when luminosity is the competition factor.
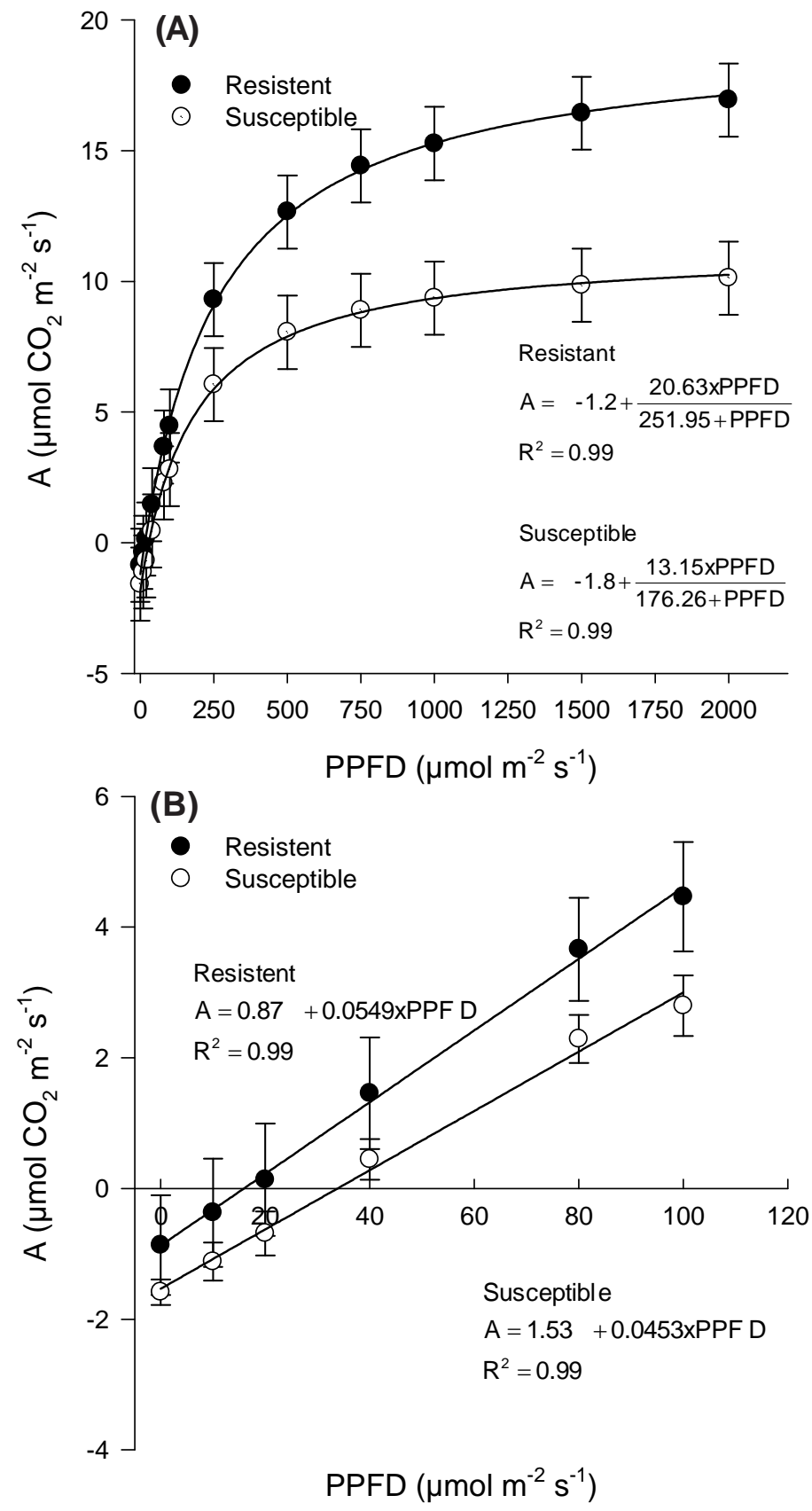

Vertical bars indicate LSD $(\mathrm{p}<0.05)$.

Figure 1 - Effect of the photosynthetic photon flow density (PPFD) in the liquid photosynthetic rate (A) and light compensation point and quantum yield (B) of glyphosate-resistant and -susceptible hairy fleabane biotypes. 


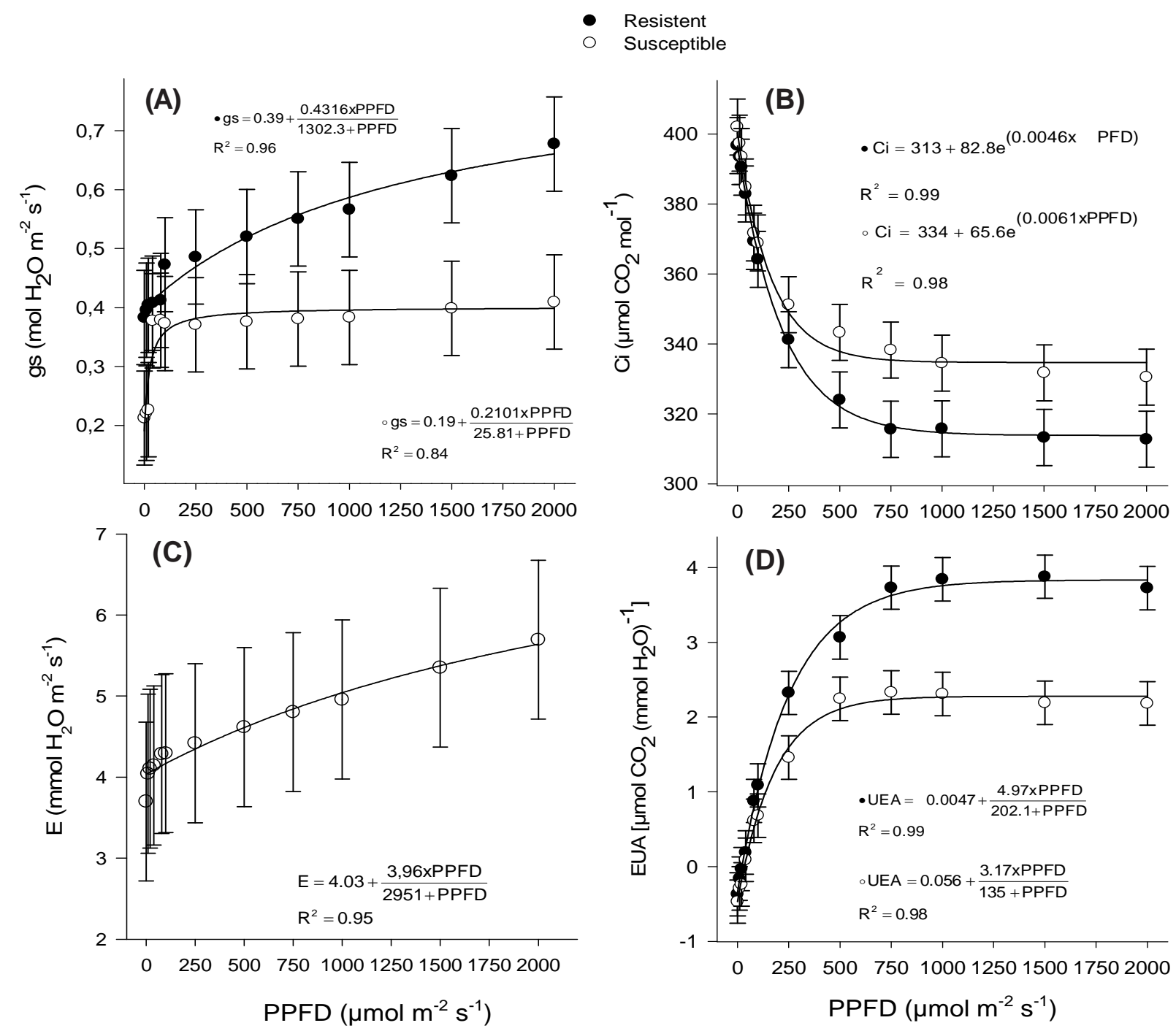

Vertical bars indicate LSD $(\mathrm{p}<0.05)$.

Figure 2 - Effect of the photosynthetic photon flow density (PPFD) in the stomatal conductance (gs) (A), substomatal $\mathrm{CO}_{2}$ concentration (Ci) (B), transpiration rate (E) (C) and instantaneous water use efficiency (WUE) (D) of glyphosate-resistant and susceptible hairy fleabane biotypes.

Quantum yield results (QY) indicate that, every 18 and $22 \mu$ mols of photons $\mathrm{m}^{2} \mathrm{~s}^{-1}$ absorbed, the plant incorporates $1.0 \mu \mathrm{mol}$ of $\mathrm{CO}_{2}$ for the biotypes $\mathrm{R}$ and $\mathrm{S}$, respectively (Figure $1 \mathrm{~B}$ ). The light compensation point (LCP) for the R biotype was estimated to be $15.84 \mu \mathrm{mol} \mathrm{m}^{-2} \mathrm{~s}^{-1}$, whereas for the $\mathrm{S}$ biotype it was $33.77 \mu \mathrm{mol} \mathrm{m}^{-2} \mathrm{~s}^{-1}$ (Figure 1B). QY and LCP indicate that the R biotype is more effective in using light energy to assimilate $\mathrm{CO}_{2}$ and it presents a positive balance in fixing carbon under low luminosity (Dias-Filho, 2002). This may be a competitive advantage for the R biotype in quickly occupying space and establish itself first in the competition, compared to biotype $\mathrm{S}$.

The liquid photosynthetic rate and the effectiveness in using luminosity that were verified in biotype R support the results found by Kaspary et al. (2015), who observed that biotype R of C. bonariensis showed a quicker development than biotype $\mathrm{S}$, with a great reproductive capacity. Associated to these characteristics, the amount of photosynthetic pigments was higher in all development stages, when compared to biotype S (Kaspary et al., 2014). Similarly, biotypes R of C. canadensis developed faster than the susceptible biotype, in the absence of competitors (Shrestha et al., 2010, 2014). In addition to this, the photosynthetic parameters (A, QY and LCP) observed for biotype R may be related to the high amount of photosynthetic pigments determined for biotype R (Kaspary et al., 2014). 
The photosynthetic parameters observed for biotype $\mathrm{R}$ prove to be more effective in converting light energy into chemical energy, both under high or low luminosity. Thus, these characteristics would be important in a situation of light competition, making it with higher competitive ability for this resource. In Rio Grande do Sul, the preferential hairy fleabane germination flow occurs during the cold season (low temperature and luminosity), when the optimal temperature for germination is close to $20^{\circ} \mathrm{C}$ and the presence of cultures in winter reduces the incidence of solar light on the soil. Under these conditions, biotype $\mathrm{R}$ could have its growth benefited in relation to biotype $\mathrm{S}$ and, thus, it would result in a more vigorous vegetative condition at the time of desiccation management for the summer cultivation, which would turn control by herbicides more complicated, since the size of the plant plays an essential role in the herbicide choice and control effectiveness (Oliveira Neto et al., 2010).

Even if the initial results of the differences in the photosynthetic parameters between biotypes $\mathrm{R}$ and $\mathrm{S}$ differentiate them, it is important to highlight that the evaluated biotypes do not have the same genetic basis, even if hairy fleabane populations have come from areas with similar weed management, with at least four years of RR soybean cultivation, at the distance of about $80 \mathrm{~km}$. Choosing a susceptible biotype from an area with a similar weed management aims at avoiding the occurrence of biotypes with different ecologic history characteristics, since susceptible biotypes coming from non-agricultural areas may present superior biological and evolutional characteristics (Shrestha et al., 2014).

The benefits in the photosynthetic parameters in relation to biotype $\mathrm{R}$ may not necessarily be related to characteristics of glyphosate resistance, but to the environmental selection pressure in these areas; the differences found would result from the biological differences between biotypes (Vila-Aiub et al., 2009), since there is no relation between the resistance mechanisms to glyphosate with losses in the eco-physiological adaptability of resistant biotypes (Vila-Aiub et al., 2014; Travlos and Chachalis, 2013; Glettner and Stoltenberg, 2015). However, the luminous intensity may be involved in the response variation of glyphosate resistance (Moretti et al., 2013).

The difference found in A between the biotypes is, mainly, the reflex of the combination of parameters such as gs and $\mathrm{Ci}$, which were changed differently between the biotypes by the increase in PPFD. Gs had a quick initial increment in both biotypes, but starting from a $250 \mu \mathrm{mol} \mathrm{m} \mathrm{m}^{-2} \mathrm{~s}^{-1} \mathrm{PPFD}$, the response to luminosity was constant for biotype $\mathrm{S}$, whereas for biotype $\mathrm{R}$ there was an increase until the last PPFD level (Figure 2A). Ci decreased for both biotypes until a PPFD of $1,000 \mu \mathrm{mol} \mathrm{m} \mathrm{m}^{-2} \mathrm{~s}^{-1}$, and after this luminosity level, the variable stabilized (Figure 2B). However, starting from a luminosity of $500 \mu \mathrm{mol} \mathrm{m}^{-2} \mathrm{~s}^{-1}$, the Ci fall for biotype R was higher than the one occurred in biotype S.

Gs is related to the quantity and size of the stomata in the leaves; a series of factors influences in the regulation of the stomata opening, from which the solar radiation performs an important action (Yang et al., 2016). Thus, biotype $\mathrm{R}$ was more effective in the gas exchange capacity (gs) facing the increase in luminosity, compared to biotype $\mathrm{S}$. This effectiveness reflected in the assimilation of $\mathrm{CO}_{2}$ (Figure $1 \mathrm{~A}, \mathrm{~B}$ ).

The stabilization of gs values facing the increase in PPFD for biotype S may be the response to the closing of stomata, caused by the accumulation of the photosynthesis final products, such as sucrose (Talbott and Zeiger, 1998). Ci has an inverse relation with A; thus, as the photosynthetic rate in the plant increases, there is a reduction in the $\mathrm{Ci}$ because of the consumption of $\mathrm{CO}_{2}$ by the substomatal chamber, which generates concentration gradient between the inside and the outside of the leaf. Ci values observed for biotype $\mathrm{S}$ may be described as indicating the lowest competition ability for light and $\mathrm{CO}_{2}$ (Concenço et al., 2008), whereas the reduced Ci observed for biotype $\mathrm{R}$ indicates higher activity of carbon fixation by RuBisCo, as it exceeds the PPFD. Thus, the gs and $\mathrm{Ci}$ observed for biotype $\mathrm{R}$ indicate a more effective balance between $\mathrm{CO}_{2}$, consumption and input, compared to biotype $\mathrm{S}$.

Gs has a tight relation with the opening of stomata and, subsequently, it is understood as a physiological mechanism to control transpiration (Messinger et al., 2006), which plays a role in the absorption of water, nutrients and foliar temperature regulation (Taiz and Zeiger, 2013), whereas luminosity has an immediate effect on the opening of stomata, influencing the gas 
exchange capacity of the plant. Thus, it was possible to verify that the biotypes presented a growing transpiration rate with the PPFD increase (Figure 2C). Even if there were gs differences between the biotypes, the same result was not verified for E. Even if gs from biotype $\mathrm{S}$ indicates a lower water flow, compared to biotype $\mathrm{R}$, the water transpiration rate was similar between the biotypes, which may be explained by the absence of water and light restriction. Similar results were observed by Alcorta et al. (2011), who did not found any difference in the transpiration rate of biotypes $\mathrm{R}$ and $\mathrm{S}$ to glyphosate when cultivated with no water restriction.

The WUE indicates the direct relation between the $\mathrm{CO}_{2}$ assimilation capacity and the amount of transpired water. Even if no differences were observed in $\mathrm{E}$ between the biotypes, biotype $\mathrm{R}$ was $41 \%$ more effective as for WUE, compared to biotype S, in the maximum PPFD (Figure 2D). This result is the reflex of the greater $\mathrm{CO}_{2}$ fixation capacity verified by biotype R. WUE may be correlated to the differential adaptation to drought conditions and it may indicate the plant potential in retaining water under adverse climate conditions (Machado et al., 2002), even if biotypes did not undergo these conditions. Shrestha et al. (2010) suggest that, in low stress environmental situations, biotypes $\mathrm{R}$ and $\mathrm{S}$ may be equally productive; however, under conditions of low water availability, it was verified that the glyphosate-resistant Conyza canadensis biotype was more competitive than the susceptible one.

Researches about the effects on the adaptation of glyphosate-resistant and -susceptible Conyza biotypes have been conflicting. Studies have identified that glyphosate-resistant biotypes do not present costs in the adaptation under competitive and non-competitive conditions (Travlos and Chachalis, 2013; Shrestha et al., 2014). Other studies demonstrated that the absolute growth of biotype $\mathrm{S}$ was higher than biotype $\mathrm{R}$ for $C$. canadensis and $C$. bonariensis coming from citrus orchard areas (Moreira et al., 2010). On the other hand, studies with C. bonariensis biotypes coming from RR soybean production areas in Rio Grande do Sul allowed inferring that biotype $\mathrm{R}$ has better competitive abilities, compared with biotype S (Kaspary et al., 2014, 2015).

Even with the absence of the selection factor (glyphosate herbicide), such as in areas at the edges of crops, the frequency of resistant populations tends to be higher, due to the selection time that the herbicide imposes over hairy fleabane plants inside the cultivation. In addition to this, the repetitive use of glyphosate limits the ecologic evolution of susceptible plants; maintaining the continuous use of glyphosate in managing weeds, resistant populations will prevail within cultivation areas and in side areas (Gage et al., 2015).

Environmental and crop management factors may select plants with different growth and development rates, due to the imposition of different selection pressures of the medium over biotypes (Shrestha et al., 2014). At the population level, the result of ecological adaptations is subjected to the level of disturbance and stresses in which plants develop (Radosevich et al., 1997). It is important to highlight that the environmental conditions of this study were partially controlled in terms of the resources available to plants. Even if differences were found in the photosynthetic parameters between biotypes $\mathrm{R}$ and $\mathrm{S}$, which support the results found in literature, it is prudent to highlight that the results obtained in this study may be different if interpreted in a generalized way.

The results of the study indicate that biotype $\mathrm{R}$ does not have penalties in its photosynthetic performance. For the biotypes at issue, responses to luminosity indicate that biotype R may have better competition conditions, mainly when the light resource is restricted. Differences between the biotypes may not be associated to resistance or susceptibility to glyphosate, but to the evolutionary characteristics of the biotypes.

\section{REFERENCES}

Alcorta M. et al. Competitive effects of glyphosate-resistant and glyphosate-susceptible horseweed (Conyza canadensis) on young grapevines (Vitis vinifera). Weed Sci. 2011;59:489-94.

Concenço G. et al. Eficiência fotossintética de biótipos de azevém em condição de competição. Planta Daninha. 2008;19:247-53.

Dauer J.T. et al. Conyza canadensis seed ascent in the lower atmosphere. Agric For Meteor. 2009;149:526-34. 
Dias-Filho M.B. Photosynthetic light response of the $\mathrm{C}_{4}$ grasses Brachiaria brizantha and B. humidicola under shade. Sci Agric. 2002;59:65-8.

Gage K.L. et al. Occurrence of an herbicide-resistant plant trait in agricultural field margins. Evol Ecol. 2015;5:4161-73.

Glettner C.E., Stoltenberg D.E. Noncompetitive growth and fecundity of Wisconsin giant ragweed resistant to glyphosate. Weed Sci. 2015;63:273-81.

Heap I.M. International Survey of Herbicide Resistant Weeds. [accessed on: 01 Jul. 2016] Available at: http:// www.weedscience.org/summary/home.aspx.

Kaspary T.E. et al. Determination of photosynthetic pigments in hairy fleabane biotypes susceptible and resistant to the herbicide glyphosate. Planta Daninha. 2014;32:417-26.

Kaspary T.E. et al. Growth, phenology and seed viability between glyphosate resistant and glyphosate susceptible hairy fleabane. Bragantia. 2015;76:92-101.

Machado E.C. et al. Variação sazonal da fotossíntese, condutância estomática e potencial da água na folha de laranjeira 'Valência' . Sci Agric. 2002;59:53-8.

Messinger S.M. et al. Evidence for involvement of photosynthetic processes in the stomatal response to $\mathrm{CO}_{2}$. Plant Physiol. 2006;140:771-8.

Moreira M.S. et al. Crescimento diferencial de biótipos de Conyza spp. resistente e suscetível ao herbicida glifosato. Bragantia. 2010;69:591-8.

Moretti M.L. et al. Glyphosate resistance is more variable than paraquat resistance in a multiple-resistant hairy fleabane (Conyza bonariensis) population. Weed Sci. 2013;61:396-402.

Oliveira Neto A.M. et al. Manejo de Conyza bonariensis com glyphosate + 2,4-D e amônio-glufosinate em função do estádio de desenvolvimento. Rev Bras Herbic. 2010;9:73-80.

Radosevich S.R., Holt S.J., Ghersa C. Weed ecology: implications for management. New York: John Wiley \& Sons, 1997. 589p.

Roman E.S. et al. Resistência de azevém (Lolium multiflorum) ao herbicida glyphosate. Planta Daninha. 2004;22;301-6.

Shrestha A. et al. Distribution of glyphosate-resistant and glyphosate-susceptible Hairy ûeabane (Conyza bonariensis) in central California and their phenological development. J Pestic Sci. 2014;87:201-9.

Shrestha A. et al. Growth, phenology, and intraspecific competition between glyphosate-resistant and glyphosate-susceptible horseweeds (Conyza canadensis) in the San Joaquin Valley of California. Weed Sci. 2010;58:147-53.

Taiz L., Zeiger E. Fisiologia vegetal. Porto Alegre: Artmed, 2013. 954p.

Talbott L.D., Zeiger E. The role of sucrose in guard cell osmoregulation. J Exp Bot. 1998;49:329-37.

Travlos I.S., Chachalis D. Relative competitiveness of glyphosate-resistant and glyphosate-susceptible populations of Hairy ûeabane, Conyza bonariensis. J Pestic Sci. 2013;86:345-51.

Vargas L. et al. Buva (Conyza bonariensis) resistente ao glyphosate na região sul do Brasil. Planta Daninha. 2007;25:573-8.

Vila-Aiub M.M. et al. No fitness cost of glyphosate resistance endowed by massive EPSPS gene amplification in Amaranthus palmeri. Planta. 2014;239:793-801.

Vila-Aiub M.M., Neve P., Powles S.B. Fitness costs associated with evolved herbicide resistance alleles in plants. New Phyt. 2009;184:751-67.

Yang Z.Q. et al. Effects of low irradiation on photosynthesis and antioxidant enzyme activities in cucumber during ripening stage. Photosynthetica. 2016;54:251-8. 